\title{
Response to Liu et al.: Rebuttal to "Effect of seasonal weather variations on the desiccation behavior of treated oil sand fine tailings" by Owolagba and Azam (Environ Earth Sci 2015, 74(2): 1711-1717)
}

\author{
John Owolagba ${ }^{1} \cdot$ Shahid Azam ${ }^{1}$
}

Received: 1 May 2016/Accepted: 5 May 2016/Published online: 13 May 2016

(C) Springer-Verlag Berlin Heidelberg 2016

\begin{abstract}
The authors thank the writers of the rebuttal for their interest in the paper. This provides an opportunity to elaborate on the scope and results of the numerical simulation study presented in the paper.
\end{abstract}

Keywords Soil-atmosphere interaction · Fluxes · Material properties · Climatic parameters

The research focused on developing a conceptual understanding of atmospheric evaporation for dewatering of surface deposits of tailings. For this purpose, a desiccation model was developed to couple material properties of treated oil sand fine tailings with climatic parameters using 30-year monthly averages. The climatic conditions of northern Alberta (Fort McMurray) allow that such a water escape occurs mainly during late summer through early fall. During this time (June-September), the air temperature remains above zero $\left(14{ }^{\circ} \mathrm{C}\right.$, as reported in Fig. 1b, Owolagba and Azam 2015), thereby precluding ground freezing and ice lens formation in the deposited tailings. Therefore, the transient seepage model was based on an equation that used hydraulic conductivity and vapor conductivity only. Further details of the governing relationships leading to the above equation can be found in Azam and Ito (2012).

The increase in degree of saturation during early winter (September-December) is attributed to the high overall precipitation during the preceding summer months (Fig. 1a, Owolagba and Azam 2015). Whereas the average air temperature for these months was analyzed to be $-7{ }^{\circ} \mathrm{C}$ (Fig. 1b,

Shahid Azam

shahid.azam@uregina.ca

1 Environmental Systems Engineering, University of Regina, Regina, SK, Canada
Owolagba and Azam 2015), air temperature in September is shown to be generally above freezing and the sub-zero air temperature in October and December does not mean an abrupt ground freezing and ice lens formation in the tailings deposit. Conversely, the decrease in degree of saturation during late winter (January-March) may be attributed to ice lens formation albeit the preclusion of this phenomenon in the governing equation. In this context, it is important to note that the runoff closely matched the precipitation trend (Fig. 2, Owolagba and Azam 2015) because percolation within the deposit was negligible owing to the low saturated hydraulic conductivity $\left(3 \times 10^{-10} \mathrm{~m} / \mathrm{s}\right)$ of the material.

Finally, the cited work of Christensen et al. (2013) is fundamentally different from the focus of this research. These authors presented in situ measurements (not long-term average values) of snowmelt infiltration (opposite of evaporation) under various topsoil cover thicknesses (different from oil sand fine tailings). Furthermore, the study area (Fort Saskatchewan) is about $400 \mathrm{~km}$ south of Fort McMurray where field monitoring was conducted over a period of about 1 year (March 2011-April 2012). Therefore, the authors feel that a comparison of their results with a short-range data of only winter conditions for a different soil is not valid.

\section{References}

Azam S, Ito M (2012) Coupled soil-atmosphere modeling for expansive Regina clay. J Environ Inf 19:20-29

Christensen AF, He H, Dyck MF, Lenore Turner E, Chanasyk DS, Naeth MA, Nichol C (2013) In situ measurement of snowmelt infiltration under various topsoil cap thicknesses on a reclaimed site. Can J Soil Sci 93(4):497-510

Owolagba J, Azam S (2015) Effect of seasonal weather variations on the desiccation behavior of treated oil sand fine tailings. Environ Earth Sci 74(2):1711-1717 